\title{
Optimization of Anthocyanin Content in Uwi Flour (Dioscorea alata) Using Response Surface Methodology
}

\author{
Ulyarti $^{1}$, Nazarudin $^{2}$, Lisani $^{1}$ \\ 1. Faculty of Agricultural Technology, University of Jambi \\ 2. Faculty of Engineering, University of Jambi \\ * contact person : ulyarti@unja.ac.id
}

\begin{abstract}
Main problem in the processing of Dioscorea alata's tuber into flour is the changing of colour. One factor in color changing is attributed to antocyanin reaction in the tuber. Several methods can be applied to minimise the browning and hence maintain the natural colour preferred by the consumers. This research was conducted to obtain the combination of age of harvest, blanching temperature and blanching length which produce the highest content of antocyanin in Dioscorea alata's flour. The responses measured was anthocyanin content. The result showed that age of harvest was the main factor for anthocyanin content of Dioscorea alata flour. The optimum anthocyanin content is predicted to be achieved by using tuber harvested at 9.6 months, temperature of blanching $\mathbf{8 6 . 1 2}^{\circ} \mathrm{C}$ and blanching time for 0.56 menit.
\end{abstract}

Keywords -Dioscorea alata's flour, anthocyanin, age of harvest, blanching

\section{INTRODUCTION}

The flour of purple Dioscorea alata is one potential product from the tuber of Dioscorea alata which can be used as partial substitute for wheat in some food products. Purple Dioscorea alata flour also contains bioactive components such as dioscorine, diosgenins, and soluble non starch polysacharide render it valuable material for functional foods. The main problem of producing purple Dioscorea alata flour is the changing in color of product due to browning reaction [1] despite the color being one of the important factor in quality determination of purple Dioscorea alata based food products. Furthermore, the purple color of Dioscorea alata flour is an indication of the presence of bioactive component antocyanin [2].

Several methods have been developed to prevent browning during the processing of Dioscorea alata tuber into flour such as inactivation of peroxidase enzymes and poliphenol oxidase (PPO) using blanching treatment $[3,4,5]$. The blanching treatment can be applied using several range of temperatures and times. Besides the temperature and length of blanching, the color of produced flour is also depend on the age of tubers when they are harvested due to the difference in PPO content [6].

This research was conducted to obtain combination of age of tuber at harvest, blanching temperature and time during the processing of purple Dioscorea alata tuber which produce flour with the highest content of antocyanins.

\section{MATERIAL AND MethodS}

\section{A. Material}

The fresh tubers of purple Dioscorea alata was harvested in Jambi City. The age of harvest were chosen according to the treatment applied.. The tubers were immeadiately stored at room temperature $\left(30^{\circ} \mathrm{C}\right)$, until further required. The chemical used were methanol and $\mathrm{H}_{2} \mathrm{SO}_{4}$. The instruments used were water bath, drying oven, color box, digital camera, computer, and Adobe Photoshop software.

\section{B. Reserach Design}

The research used Box-Behnken design (Table 1) with age of tuber at harvest in month $\left(\mathrm{X}_{1}\right)$, blanching temperature in degrees Celcius $\left(\mathrm{X}_{2}\right)$ and blanching time in minutes $\left(\mathrm{X}_{3}\right)$ were the independent variabels. Each variable had three levels

TABLE 1

RESEARCH DESIGN

\begin{tabular}{ccccccc}
\hline \multirow{2}{*}{$\begin{array}{c}\text { Eksperimen } \\
\text { Number }\end{array}$} & \multicolumn{2}{c}{$\begin{array}{c}\text { The code for } \\
\text { eksperimen }\end{array}$} & \multicolumn{4}{c}{ Treatments } \\
\cline { 2 - 7 } & $\mathrm{X}_{1}$ & $\mathrm{X}_{2}$ & $\mathrm{X}_{3}$ & $\begin{array}{c}\mathrm{X}_{1} \\
\text { (month) }\end{array}$ & $\begin{array}{c}\mathrm{X}_{2} \\
\left({ }^{\circ} \mathrm{C}\right)\end{array}$ & $\begin{array}{c}\mathrm{X}_{3} \\
(\mathrm{~min})\end{array}$ \\
\hline 1 & -1 & -1 & 0 & 9 & 70 & 10 \\
\hline 2 & -1 & 1 & 0 & 9 & 90 & 10 \\
\hline 3 & 1 & -1 & 0 & 11 & 70 & 10 \\
\hline 4 & 1 & 1 & 0 & 11 & 90 & 10 \\
\hline 5 & -1 & 0 & -1 & 9 & 80 & 5 \\
\hline 6 & -1 & 0 & 1 & 9 & 80 & 15 \\
\hline 7 & 1 & 0 & -1 & 11 & 80 & 5 \\
\hline 8 & 1 & 0 & 1 & 11 & 80 & 15 \\
\hline 9 & 0 & -1 & -1 & 10 & 70 & 5 \\
\hline 10 & 0 & -1 & 1 & 10 & 70 & 15 \\
\hline 11 & 0 & 1 & -1 & 10 & 90 & 5 \\
\hline 12 & 0 & 1 & 1 & 10 & 90 & 15 \\
\hline 13 & 0 & 0 & 0 & 10 & 80 & 10 \\
\hline 14 & 0 & 0 & 0 & 10 & 80 & 10 \\
\hline 15 & 0 & 0 & 0 & 10 & 80 & 10 \\
\hline
\end{tabular}




\section{Flour preparation:}

The production of flour from the tuber of purple Dioscorea alata was following the methods described previously (Ulyarti \& Fortuna, 2016) without citric acid.

\section{Respond Analysis}

The respond analysed was the anthocyanin content [7]. One gram of flour was extracted using $10 \mathrm{ml}$ methanol-acid prepared by mixing 95\% methanol and $1 \mathrm{~N} \mathrm{HCl}$ at ratio 85:15 $(\mathrm{v} / \mathrm{v})$. The sample was flushed by using nitrogen, shaked for 30 minutes and sentrifused at $3000 \mathrm{~g}$ for 10 menit. Supernatant was separated and used spectrophotometer reading at $\lambda 535$ dan $700 \mathrm{~nm}$. Anthocyanin content was calculated using the following formula:

$C=\left[\frac{A_{535 \mathrm{~nm}}-A_{700 \mathrm{~nm}}}{\varepsilon}\right] *($ total volume methanol extract $) * M W *$

Where:

$\mathrm{C}=$ Total anthocyanin content $(\mathrm{mg}$ cyanidin 3 -glucoside equivalents/gram sample)

$\varepsilon=$ Molar absorptivity (untuk cyanidin 3-glucoside $=25,965 / \mathrm{cm} / \mathrm{M}$ )

$\mathrm{MW}=$ Molecular weight cyanidin 3-glucoside yaitu 449,2 g/mol

\section{Data Analysis}

Second orde model was used :

$Y=\beta_{0}+\beta_{1} X_{1}+\beta_{2} X_{2}+\beta_{3} X_{3}+\beta_{1.2} X_{1} X_{2}+\beta_{1.3} X_{1} X_{3}+\beta_{2.3} X_{2} X_{3}$ $+\beta_{1.1} X_{1}^{2}+\beta_{2.2} X_{2}^{2}+\beta_{3.3} X_{3}^{2}+\varepsilon$

where :

$\mathrm{X}_{1}=$ age of harvest

$\mathrm{X}_{2}=$ blanching temperature

$\mathrm{X}_{3}=$ blanching length

Respond (Y) was dependent variabel (anthocyanin content). Coefisien $\beta$ were determined by using least significant squares. The acceptance or rejection of proposed math model was determined by looking at the determination coefficient $\left(\mathrm{R}^{2}\right)$ and the significance for lack of fit test.

\section{RESUlT AND DisCUSSION}

\section{Anthocyanin Content}

Antocyanin content of several combination of treatments for flour production is presented at Fig 1. The surface plots and contour plots for their anthocyanin content can be seen at Fig 2.

The condition of each run was set according to experiment number shown in Table 1 . As the last three runs were the repitition of the same combination of treatments, the quite similar values for these three runs showed that the experiments were carried out quite precisely. The highest antocyanin content $(78.5 \mathrm{mg} / \mathrm{g})$ was produced from age of tuber at harvest 10 months, blanching temperature $90^{\circ} \mathrm{C}$, and blanching time 5 minutes (run 11).

Antocyanin content in the potato tuber is known to be influenced by the flesh colour, growing area and year of planting [8]. Similar factors may influence antocyanin content in Dioscorea alata tubers. Biosynthesis of anthocyanin is known to occur during the same time as tuber initiation, hence the content of anthocyanin in tuber may change during growth. Current experiment showed that the increasing in age of tuber at harvest in one case increased anthocyanin content of the flour (run no 1 and 3 ) but in other case decreased the anthocyanin content (run no 5 and 7). The last case was in agreement with a study from [9] which showed that anthocyanin content in the color-fleshed potato was decreasing during the maturation.

Similar result for the influence of age of tuber during harvest was found for blanching temperature. The increasing in blanching temperature in flour production in one case increased anthocyanin content of the flour (run no $3 \& 4 ; 9 \& 11$ ) but in other case decreased the anthocyanin content (run no 1 and 2). Anthocyanin is known to degrade during heating process. Its degradation occurs at faster rate at higher temperature [10].

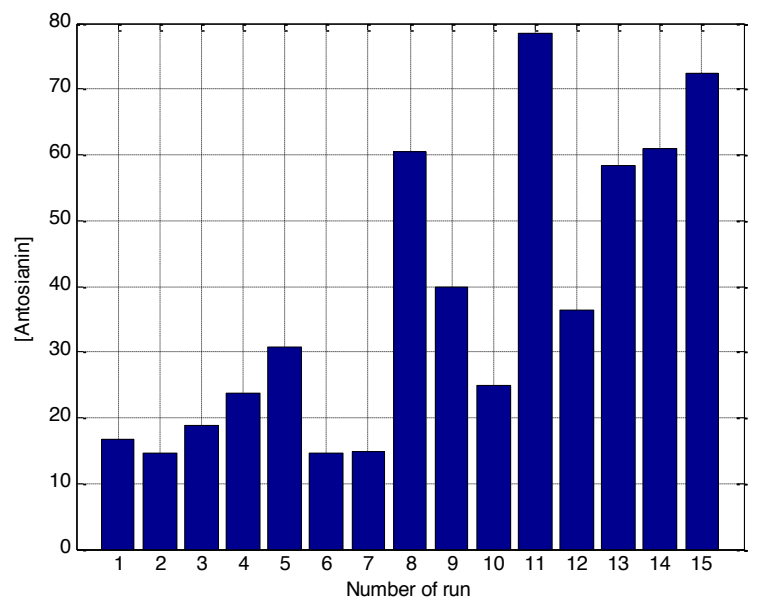

FIG 1. Anthocyanin Content of Flour Made Using Several Combinations Of Treatments

\section{Optimum Condition}

The optimum condition was calculated using the equation generated from the experiment. Based on the data on Fig 1, the equation for anthocyanin content is as follow:

$$
\begin{gathered}
\mathrm{Y}=63.8533+5.1313 \mathrm{X}_{1}+6.6075 \mathrm{X}_{2}-3.4513 \mathrm{X}_{3}+1.7400 \\
\left(\mathrm{X}_{1}\right)^{2}+15.4275\left(\mathrm{X}_{2}\right)^{2}-6.7750\left(\mathrm{X}_{3}\right)^{2}-30.0554 \mathrm{X}_{1} \mathrm{X}_{2}-15.3079 \\
\mathrm{X}_{1} \mathrm{X}_{3}-3.5704 \mathrm{X}_{2} \mathrm{X}_{3}
\end{gathered}
$$

The statistical analysis for the above model is presented in Table 2. This equation showed a high determination coefficient 0.81 means that the model is accepted. The acceptance of the model is also showed by lack of fit test which gave non significant lack of fit for the above model. By looking at $\lambda$ values, the most influencing factors are as follow: age of the plant at harvest followed by blanching temperature and blanching time. The optimum anthocyanin content is predicted to be achieved by using tuber harvested at 9.6 months, temperature of blanching $86.12^{\circ} \mathrm{C}$ and blanching time 
for 0.56 menit. At these condition, the optimum anthocyanin content was obtained at $68,15 \mathrm{mg} / \mathrm{gram}$ flour.
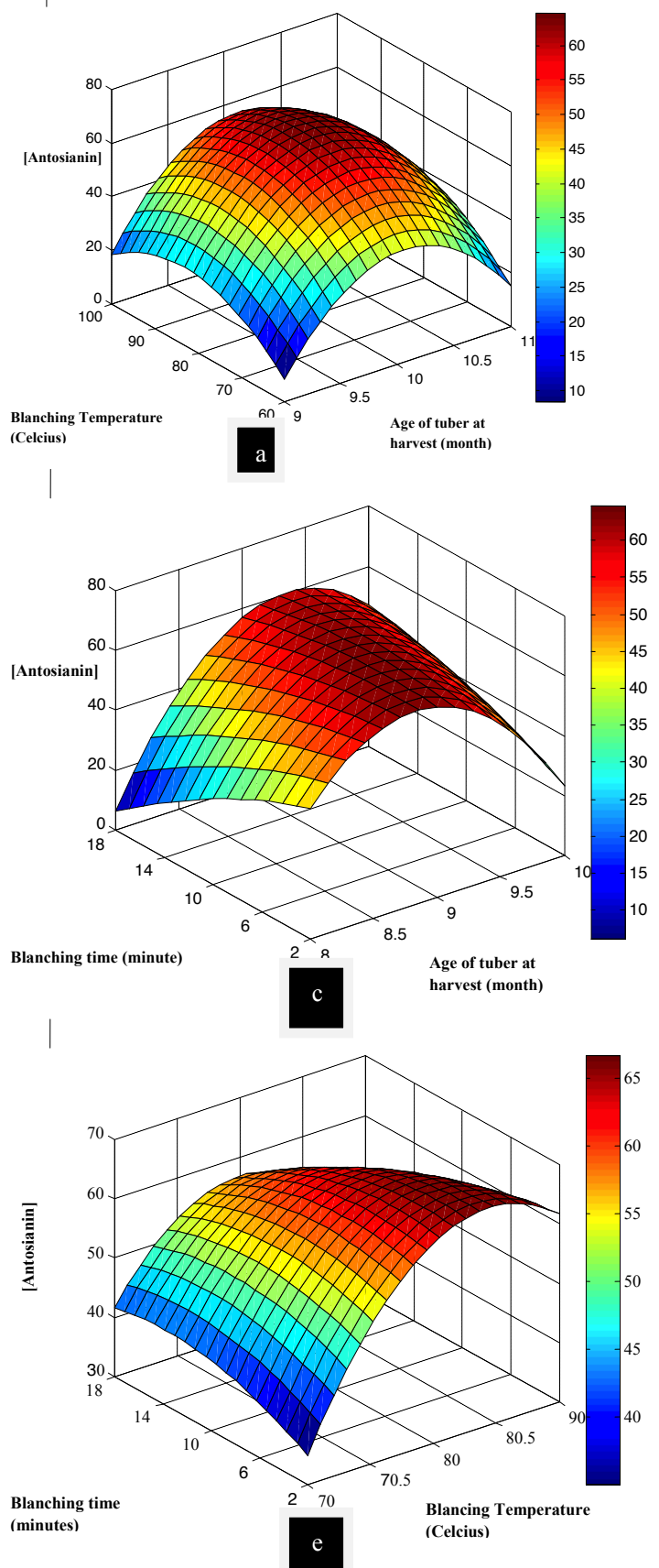

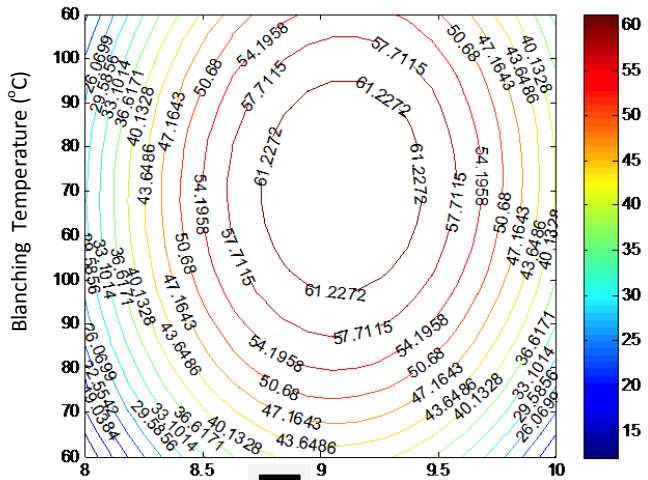

b Age at Harvest (Month)
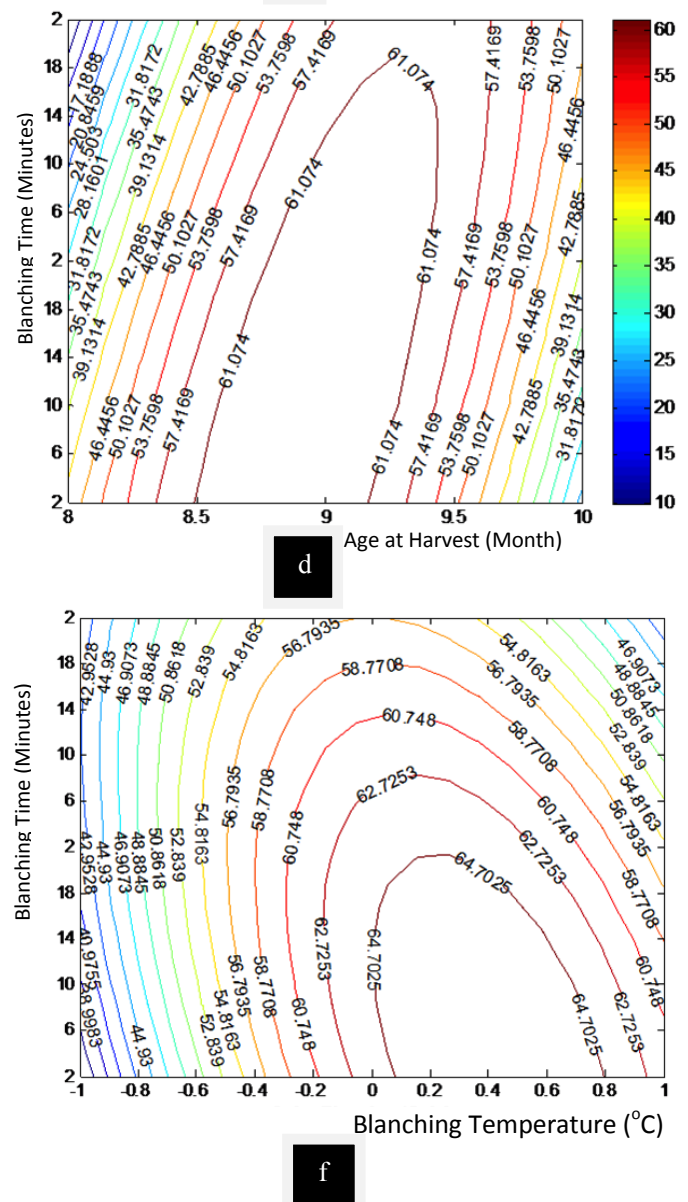

Fig 2. Surface plots (a) and contour plots (b) for anthocyanin content of flour made at blanching time 10 minutes; Surface plots (c) and contour plots (d) of flour made at blanching temperature $80^{\circ} \mathrm{C}$; and Surface plots (e) and contour plots (f) of flour made at age of tuber 10 months 
TABLE 2

Statistical Analysis For Model Of AnThocyanin CONTENT OF UWi FLOUR

\begin{tabular}{|c|c|c|c|}
\hline \multirow{3}{*}{$\begin{array}{l}\text { Eigen } \\
(\lambda)\end{array}$} & \multirow[t]{3}{*}{ values } & Age of harvest $\left(\mathrm{X}_{1}\right)$ & \multirow{2}{*}{$\begin{array}{r}-32.3159 \\
-15.7749\end{array}$} \\
\hline & & $\begin{array}{l}\text { Blanching Temperature } \\
\left(\mathrm{X}_{2}\right)\end{array}$ & \\
\hline & & Blanching Time $\left(\mathrm{X}_{3}\right)$ & -0.8430 \\
\hline \multirow[t]{4}{*}{$\mathrm{R}^{2}$} & & & $80.79 \%$ \\
\hline & \multicolumn{2}{|c|}{ F Lack of Fit } & 7.29 \\
\hline & \multicolumn{2}{|c|}{$\mathrm{F}$ table $5 \%$} & 19.16 \\
\hline & \multicolumn{2}{|c|}{ Model accepted } & Yes \\
\hline
\end{tabular}

\section{CONCLUSION}

It could be concluded that age of harvest was the most influencing factor for anthocyanin content in Dioscorea alata's flour, followed by blanching temperature and blanching time. The highest anthocyanin content in Dioscorea alata's flour can be obtained by processing tuber harvested at 9.6 months, temperature of blanching $86.12^{\circ} \mathrm{C}$ and blanching time for 0.56 menit.

\section{REFERENCES}

[1] Akubor. 2008. Effect Ascorbic Acid and Citric Acid Treatments on The Functional and Sensory Properties of Yam Flour. Int. J. Agric. Pol. Res, vol. 1, ed. 4, pp.103-108.

[2] Wang, W., \& Xu, S. 2007. Degradation kinetics of anthocyanins in blackberry juice and concentrate. Journal of Food Engineering , 271275.

[3] Akissoe, N., Hounhouigan, J., Mestres, C., \& Nago, M. 2003. How Blanching and Drying Affect the Colour and Functional Characteristics of Yam (Dioscorea Cayenensis-rotundata) Flour. Food Chemstry, 82 , 257-264.

[4] Ezeocha, V., \& Ojimelukwe, P. 2012. The Impact of Cooking on The Proximate Composistion and Anti-nutritional factors of Water Yam (Dioscorea alata). Journal of Stored Products and Postharvest Research, 3(13) , 172-176.

[5] Ulyarti, \& Fortuna, D. 2016. Aplikasi metode simple digital imaging untuk memprediksi pembentukan warna tepung hasil pengolahan umbi uwi ungu (Dioscorea alata). Jurnal Penelitian Universitas Jambi Seri Sain, 01-08.

[6] Huang, C., Chiang, P., Chen, Y., \& Wang, C. 2007. Chemical compositions and enzyme activity changes occuring in yam (Dioscorea alata L) tubers during growth. $L W T, 1498-1506$.
[7] Chavez-Santoscoy, R., Gutierrez-Uribe, J., Serna-Saldivar, S., \& PerezCarrillo, E. (2016). Production of maize tortillas and cookies from nixtamalized flour enriched with antocyanins, flavonoids, and saponin extracted from black bean (Phaseolus vulgaris) seed coats. Food Chemistry, 90-97.

[8] Hejtmankova, K., Kotikova, Z., Hamouz, K., pivec, V., \& vacek, J. 2013. Influence of flesh colour, year and growing area on caretonoid and anthocyanin content in potato tubers. Food Composition and Analysis, 20-17.

[9] Miloslav, S., Zora, K., Lubos, P., Vladimir, P., Karel, H., \& Jaromir, L. 2017. Changes in anthocyanidin levels during the maturation of colorfleshed potato (Solanum tuberosum L) tubers. Food Chemistry, http://dx.doi.org/10.1016/j.foodchem.2017.05.155.

[10] Kirca A, M. Ozkan, amd B Cemerogu. 2007. Effect of temperature, solid content and $\mathrm{pH}$ on the stability of black carrot anthocyanins. Food Chem, vol. 101, pp. 212-218. 